\title{
GYULLADÁSOS BÉLBETEGSÉGEK BIOLÓGIAI KEZELÉSE 2018-BAN
}

\section{BIOLOGICAL THERAPIES IN INFLAMMATORY BOWEL DISEASES IN 2018}

\author{
Miheller Pál ${ }^{1,2}$, Mihály Emese ${ }^{1,3}$, Tulassay Zsolt ${ }^{1,4}$ \\ 'Semmelweis Egyetem II. sz. Belgyógyászati Klinika, Budapest \\ 2PhD, egyetemi docens, miheller.pal@med.semmelweis-univ.hu \\ 3egyetemi adjunktus, mihaly.emese@med.semmelweis-univ.hu \\ ${ }^{4}$ az MTA rendes tagja, egyetemi tanár, tulassay.zsolt@med.semmelweis-univ.hu
}

\section{ÖSSZEFOGLALÁS}

\begin{abstract}
A biológiai kezelés forradalmasította a gyulladásos bélbetegségek terápiáját. Míg korábban a betegséggel szemben véletlenszerűen megtalált hatóanyagokat alkalmaztunk, felépítő kezelési stratégia szerint, addig a biológiai kezelésekkel az alapkutatások eredményeinek megfelelő terápiás célpontokat igyekszünk gátolni. A család első képviselői az anti-TNF-szerek voltak, ezekből a kiméra infliximab és a humán adalimumab van forgalomban az Európai Unióban. Hatékonyságuk a gyulladásos bélbetegségek mindkét formájában (Crohn-betegség, colitis ulcerosa), extraintesztinális manifesztációkban is igazolt. Az újabb molekulacsalád, az integringátlók közül gyulladásos bélbetegségben a vedolizumabot alkalmazzuk. Emésztőszervi szelektivitása számos biztonságossági előnnyel jár, emésztőszerven kívüli tünetek kezelésére nem alkalmas. Hatáskezdete lassú, így sürgős esetek kezelésére nem használjuk, ugyanakkor hatásosságát jól megőrzi. Az ustekinumab az I-L12 és IL-23 citokinek hatását gátolja, Crohn-betegségben alkalmazható. Egyelőre második vonalban alkalmazva van kellő mennyiségű tapasztalatunk, anti-TNF-szerre priméren nem reagáló vagy pszoriázissal szövődött Crohn-betegségben a legjobb elérhető választás. A terápiás paletta bővülésével és a jósló tényezők megismerésével a jövőben lehetővé válhat az egyedileg választott biológiai vagy egyéb kezelési metodika megválasztása.
\end{abstract}

\section{ABSTRACT}

Biological therapy revolutionized the treatment of inflammatory bowel diseases. Two decades ago we applied medications with unknown mechanism of action, and we used them in a step up manner. Today we have the possibility to use biological medications with a known target of action. First members of the family of biologicals were the anti-tumour necrosis factor alpha inhibitors. We use the chimeric infliximab and the fully human adalimumab in the European Union. Their efficacy in both types of inflammatory bowel diseases (Crohn's disease, ulcerative colitis) and in their extraintestinal manifestations are well known. Vedolizumab, a member of a novel group of biologicals, the integrin-antagonisers is also achievable in our practice. Its gut-related selectivity warrants many safety benefits, however, due to this feature vedolizumab is not applicable in patients with severe extraintestinal manifestation. Start of its action is slow, but it holds up for a long time in case of a successful induction therapy. Ustekinumab inhibits IL-12 and 
IL-23 cytokines, it is licenced in Crohn's disease. Most of our experience derives from patients who were already treated with tumour necrosis factor inhibitors. Ustekinumab is probably the best choice in case of primary non-response to tumour necrosis factor inhibitors, or in patients suffering psoriasis and Crohn's disease at the same time. Due to increasing number of medications and with progressing our knowledge on predictor factors regarding the efficacy of the different therapeutic methods, we will have an opportunity to plan an individual therapy for our inflammatory bowel disease patients.

Kulcsszavak: biológiai kezelés, Crohn-betegség, colitis ulcerosa, infliximab, adalimumab, vedolizumab, ustekinumab

Keywords: biological therapy, Crohn's disease, ulcerative colitis, infliximab, adalimumab, vedolizumab, ustekinumab

\section{BEVEZETÉS}

Az immunológiai kóreredetủ idült gyulladásos megbetegedések (immune mediated inflammatory disorders, IMID) leggyakrabban az ízületeket, a bőrt és az emésztőszerveket érintik. Az IMID-betegségek emésztőszervi képviselői a gyulladásos bélbetegségek (inflammatory bowel diseases, IBD), ide tartozik a Crohnbetegség (CD) és a colitis ulcerosa (UC). A mozgásszervi és bőrgyógyászati IMID-betegségek kezelési szemléletéhez hasonlóan, az IBD kezelési stratégiáját is forradalmasította a biológiai kezelés.

A biológiai kezelésben alkalmazott gyógyszerek a korábbiakkal ellentétben nagy molekulatömegü, fehérjetermészetü anyagok, legtöbbször antitestek. Elöállításuk nem kémiai, hanem biológiai úton történik. Általában valamilyen sejtvagy baktériumkultúrán termelik ezeket a fehérjéket. A biológiai szerek fejlesztése során az alapkutatás eredményeit alkalmazzák, és az egyes betegségekben mért megnövekedett proinflammatórikus citokin túlsúlyt csökkentik célzott antitestekkel. Elméletileg lehetséges lenne antiinflammatórikus citokinek - mint például interleukin 10 (IL-10) - alkalmazása, de egyelőre az ilyen készítményekkel végzett klinikai vizsgálatok nem vezettek sikerre.

\section{ANTI-TNF-SZEREK}

Az IBD-ben elsőként alkalmazott biológiai kezelés a humán-murin kiméra IgG1 típusú tumornekózisfaktor-alfa (TNF-alfa) ellenes monoklonális antitest, az infliximab volt. A kiméra antitestet nagyon hamar követte a humán adalimumab, majd valamivel később a golimumab. Érdekes, hogy az ugyanúgy anti-TNF-csa- 
ládba tartozó fúziós proteinek, az etanercept és onarcept IBD-ben nem hatékonyak, bár az etanerceptet más IMID-betegségekben sikerrel alkalmazzák.

$\mathrm{Az}$ anti-TNF-szerek hatékonyságukat IBD-ben csaknem húsz éve bizonyították. Alkalmasak a hagyományos kezelésre nem reagáló vagy arra allergiás reakciót adó gyulladásos típusú CD vagy UC kezelésére. Javasolják őket penetráló típusú, legtöbbször a perianális régiót támadó, sipolyozó CD kezelésére is. Jó hatékonysággal alkalmazzuk az anti-TNF-szereket immunszupprimáns kezelés ellenére fennálló szteroidfüggőség esetén, mindkét IBD-típusban. Az anti-TNF-szerek alkalmazása ezekben az indikációkban ma már tankönyvi adat.

A gyógyszercsoporttal kapcsolatos, a közelmúltban bevezetett biohasonló (bioszimiler) gyógyszerek szerepe a költséghatékonyságuk miatt egyre növekszik. A biohasonló szerek a referenciakészítménnyel megegyező molekulaszerkezetủ és biológiai tulajdonságú gyógyszerek, melyek funkcionális hasonlóságát klinikai vizsgálatok igazolták. Az IMID-betegségekben alkalmazott infliximab-biohasonlóval kapcsolatban csak reumatológiai indikációval történt olyan klinikai vizsgálat, mely a biohasonlóságot igazolta (Yoo et al., 2013). Az egyes országokban az árkülönbség miatt a finanszírozó által hozott döntéseket kellett az orvosszakmának követnie gyulladásos bélbetegségekben. A posztmarketing elemzések mind Európában, mind hazánkban végül is azt az eredmény hozták, hogy a biohasonló infliximab ugyanolyan hatékony és biztonságos, mint a referenciakészítmény (Gönczi et al., 2017; Jørgensen et al. 2017). Újabb kérdést vet fel az árverseny által teremtett speciális helyzet, amikor biohasonlóról ismét a referenciakészítményre kell váltani, nem orvosi, hanem gazdasági okok miatt.

\section{ANTI-INTEGRIN-GÁTLÓK}

Az integringátlók hatásmechanizmusának lényege, hogy a gyulladásos fehérjéket nem engedik kiáramlani a kapilláris falon keresztül a szöveti térbe. Azt a ligand-receptor kapcsolatot gátolják, amely a leukociták endotélhez (érfalhoz) való kötődéséhez elengedhetetlen.

A gyógyszercsoport klinikai alkalmazásra került első képviselője a natalizumab volt, mely nem szelektíven gátolta az összes olyan integrint, melyben alfa4-lánc szerepelt. Bár CD-ben klinikai hatékonyságot mutatott (Sandborn et al., 2005), egy súlyos központi idegrendszeri mellékhatás, a JC-vírus aktiválásával bekövetkezett progresszív multifokális leukoenkefalopátia miatt IBD-ben nem alkalmazható.

A csoport következö, már törzskönyvvel, nemzetközi és hazai tapasztalatokkal is bíró tagja a vedolizumab (VDZ). Ez az antiintegrin az alfa4-béta7-integrin alegységet gátolja, mely csak az emésztőrendszer endotél sejtjein található. Hatékonyságát UC-ben (Feagan et al., 2013) és CD-ben (Sandborn et al., 2013) 
egyaránt igazolták. Összességében a VDZ mindkét kórképben hatékony indukciós és fenntartó kezelésnek bizonyult, illetve mindkét fó IBD-csoport esetében hatékony szteroidspóroló szernek tartható. Az amerikai és európai gyógyszerhatóságok engedélye után számos adat jelent meg a VDZ klinikai hatékonyságáról a való életben, vagyis kevésbé válogatott betegcsoportban. Ezek az adatok - mint csaknem mindegyik biológiai szer esetén - azt mutatják, hogy a VDZ hatékonysága nagyobb arányú, mint ahogyan azt a klinikai vizsgálatok eredményei alapján vártuk volna (Britt et al., 2018; De Vos et al., 2018; Engel et al., 2018). Hazánkban a kezelőorvosok által benyújtott kérelem alapján egy szakértői bizottság dönti el, hogy melyik betegnél indokolt a VDZ-kezelés. Az első 41 beteg (16 CD és 25 UC) adatainak feldolgozását követően a VDZ indukciós kezelésre a betegek 80,49\%-a mutatott megfelelő terápiás választ, és komplett remissziót 19 esetben (46,34\%) értünk el. Ebböl a szteroidmentes remisszió aránya 19,51\% volt (Bor et al., 2017).

Általánosságban elmondható, hogy a vedolizumab új lehetőség azoknak a betegeknek, akik biológiai kezelésre szorulnak. Klinikai tapasztalat elsősorban az anti-TNF-szerekre már nem reagáló vagy arra mellékhatást, esetleg szövődményt mutató betegek körében áll rendelkezésre. Biológiailag naív betegcsoportban minden bizonnyal a VDZ-kezelés hatékonyabbnak bizonyulhat annál, mint amit a befogadás hátterét képező klinikai vizsgálatok és a jelenleg rendelkezésre álló, valós betegcsoportok eredményei sejtetnek. A gyógyszertől természeténél fogva nem várható, hogy az emésztőrendszeren kívüli megjelenési formák kezelését is segítse, bár az alapbetegség gyógyulásával az ilyen természetü tünetek is javulhatnak. A jelenleg rendelkezésre álló adatok alapján a VDZ hatáskezdete kissé lassabb az anti-TNF szerekénél, ezért bélmentő kezelésre nem alkalmas.

\section{USTEKINUMAB}

Már a TNF-gátlók fejlesztésének idejében megindultak a kutatások más olyan citokinek után, melyek gátlása terápiás előnyt jelenthet IBD-ben. Számos, a gyulladásos folyamatot elösegítő jelátvivő molekula közül végül a T-helper sejtek differenciálódását elősegítő IL-12 és IL-23 gátlása hozta meg a várt sikereket. A két

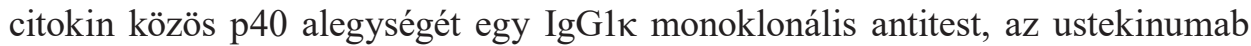
(UST) gátolni képes. Az UST felezési ideje mintegy három hét, és ugyanolyan IgG-eliminációs mechanizmussal tünik el a keringésböl, mint az anti-TNF-szerek. Az UST hatékonyságát elöször nem emésztőszervi IMID-betegségekben, majd ezt követően Crohn-betegségben (Feagan et al., 2016) bizonyították. A napi gyakorlatban az UST esetében is azt tapasztalták, hogy nagyobb arányban gyógyítja a betegeket, mint az a klinikai vizsgálati eredmények alapján várható lett volna (Ma et 
al., 2017). Az együtt alkalmazott immunszupprimánsok - az anti-TNF-szerekhez hasonló módon - tovább javítják a kezelés hatékonyságát.

Érdekes, visszatérő megfigyelés, hogy az anticitokin kezeléseknél a kezelés mellett bekövetkező állapotrosszabbodás kockázatát az együttesen alkalmazott immunszupprimáns kezelés csökkenti. Az elsősorban anti-TNF-szereken szerzett tapasztalatok azt mutatják, hogy az immunszupprimánsok csökkentik a gyógyszerellenes antitest képződését, ezzel csökkentve a relapszus hajlamot. A nem anticitokin hatásmechanizmusú, hanem antiintegrin típusú vedolizumabnál ilyen, az anitestképződés és a hatásvesztés közötti megfigyelést nem írtak le, bár ellenanyag képződés ott is kimutatható.

Hazánkban IBD-indikácóban az UST 2018 tavasza óta érhető el, egyelöre csak különleges finanszírozási feltételekkel, ezért következtetés levonására alkalmas hazai adatok még nem gyültek össze.

Összességében elmondható, hogy az UST Crohn-beteségben hatékony indukciós és fenntartó kezelési lehetőség. Ez a gyógyszer is akkor hat a legjobban, ha nem más biológiai szer után alkalmazzuk, illetve a valós életből nyert tapasztalatok azt mutatják, hogy érdemes az UST-t is immunszupprimáns szerekkel kombinálni. Figyelembe véve az UST egyéb indikációs területeit, minden bizonnyal elsőként választandó szer lehetne a pszoriázissal szövődött Crohn-betegség esetében, illetve a lokális kezelésre nem reagáló, anti-TNF-szerek okozta pikkelysömörrel szövödött CD-esetekben.

Újabban az IBD kezelésében megjelentek a nem fehérje természetü, szintetikus kismolekulák, melyek közül a tofacitinib CU-ban való hatékonyságát sikerült igazolni (Sandborn et al., 2017). Biztató kísérletek folynak az IBD válogatott eseteiben hemopoetikus és mezenchimális össejt kezeléssel is (Lopez-Garcia et al., 2017; Panes et al., 2016).

\section{ÖSSZEFOGLALÁS}

A biológiai kezelés megváltoztatta a terápiás szemléletet minden krónikus gyulladásos betegséggel foglalkozó diszciplínában. A csoport úttöröit, az anti-TNFszereket hosszú ideje alkalmazzuk, mára szinte a szokványos terápiás rezsim részét képezik. Ezt igazolja, hogy egy harmadlagos IBD-centrum betegeinek csaknem 20\%-a biológiai kezelésen, döntő hányadban anti-TNF-szeren van.

Az alapkutatások eredményeinek gazdagodásával egyre újabb és újabb hatásmechanizmusú biológiai szerek állnak rendelkezésre az IBD-kezelésében is. Crohn-betegségben és colitis ulcerosában is alkalmazható az integringátló vedolizumab. Csak Crohn-betegségben indikált, a más citokincsalád működését gátló készítmény az ustekinumab. Újabban kismolekulák és az őssejtkezelés is feltünnek a terápiás palettán. 
Az újabb gyógyszerekkel szerzett tapasztalatok alapján a következő évek feladata az lesz, hogy meghatározzuk azt a betegprofilt, amely az egyes készítmények szempontjából ideális. A különböző jósló tényezők megtalálásával elérhető lenne az, hogy már a kezelés megkezdése elött nagy valószínüséggel ki tudjuk választani az ideális gyógyszert az adott betegnek, megszűntetve ezzel az uniform piramiselvű kezelési stratégiákat.

\section{IRODALOM}

Bor R. - Molnár T. - Szamosi T. et al. (2017): Vedolizumab indukciós kezelés hatékonysága a hazai gyakorlatban. Central European Journal of Gastroenterology and Hepatology, 3, 71-75. http:// ceu-jgh.org/views/article.php?id=108

Britt, C. - Ruben, J. C. - Dejan, M. et al. (2018): Vedolizumab as Induction and Maintenance for Inflammatory Bowel Disease: 12-Month Effectiveness and Safety. Inflammatory Bowel Diseases, 24, 849-860. DOI: 10.1093/ibd/izx067, https://bit.ly/2xuJKOG

De Vos, M. - Dhooghe, B. - Vermeire, S., et al. (2018): Efficacy of Vedolizumab for Induction of Clinical Response and Remission in Patients with Moderate to Severe Inflammatory Bowel Disease Who Failed at Least Two TNF Antagonists. United European Gastroenterology Journal, 6, 439-445. DOI: 10.1177/2050640617722310, https://journals.sagepub.com/doi/ full/10.1177/2050640617722310

Engel, T. - Ungar, B. - Kopylov U. et al. (2018): Vedolizumab in IBD-lessons from Real-world Experience; A Systematic Review and Pooled Analysis. Journal of Crohn's and Colitis, 12, 245-257. DOI: 10.1093/ecco-jcc/jjx143, https://academic.oup.com/ecco-jcc/article/12/2/245/4565692

Feagan, B. G. - Rutgeerts, P. - Sands, B. E. et al. (2013): Vedolizumab as Induction and Maintenance Therapy for Ulcerative Colitis. The New England Journal of Medicine, 369, 699-710. DOI: 10.1056/NEJMoa1215734, https://www.nejm.org/doi/full/10.1056/NEJMoa1215734

Feagan, B. G. - Sandborn, W. J. - Gasink, C. et al. (2016): Ustekinumab as Induction and Maintenance Therapy for Crohn's Disease. The New England Journal of Medicine, 375, 1946-1960. DOI: $\quad 10.1056 /$ NEJMoa1602773, https://www.nejm.org/doi/10.1056/NEJMoa1602773?url_ ver=Z39.88-2003\&rfr_id=ori\%3Arid\%3Acrossref.org\&rfr_dat=cr_pub\%3Dwww.ncbi.nlm. nih.gov

Gönczi L. - Gecse K. B. - Végh Zs. et al. (2017): Long-term Efficacy, Safety, and Immunogenicity of Biosimilar Infliximab After One Year in a Prospective Nationwide Cohort. Inflammatory Bowel Diseases, 23, 1908-1915. DOI: 10.1097/MIB.0000000000001237

Jørgensen, K. K. - Olsen, I. C. - Goll, G. L. et al. (2017): Switching from Originator Infliximab to Biosimilar CT-P13 Compared with Maintained Treatment with Originator Infliximab (NORSWITCH): A 52-Week, Randomised, Double-blind, Non-inferiority Trial. The Lancet, 389, 2304-2316. DOI: 10.1016/S0140-6736(17)30068-5

Lopez-Garcia, A. - Rovira, M. - Jauregui-Amezaga, A. et al. (2017): Autologous Haematopoietic Stem Cell Transplantation for Refractory Crohn's Disease: Efficacy in a Single-centre Cohort. Journal of Crohn's and Colitis, 11, 1161-1168. DOI: 10.1093/ecco-jcc/jjx054, https://academic. oup.com/ecco-jcc/article/11/10/1161/3610532

Ma, C. - Fedorak, R. N. - Kaplan, G. G. et al. (2017): Long-term Maintenance of Clinical, Endoscopic, and Radiographic Response to Ustekinumab in Moderate-To-Severe Crohn's Disease: 
Real-world Experience from a Multicenter Cohort Study. Inflammatory Bowel Diseases, 23, 833-839. DOI: 10.1097/MIB.0000000000001074, https://bit.ly/2XtCKfq

Panes, J. - García-Olmo, D. - Van Assche, G. et al. (2016): Expanded Allogeneic Adipose-derived Mesenchymal Stem Cells (Cx601) for Complex Perianal Fistulas in Crohn's Disease: A Phase 3 Randomised, Double-blind Controlled Trial. The Lancet, 388, 1281-1290. DOI: 10.1016/S01406736(16)31203-X

Sandborn, W. J. - Colombel, J. F. - Enns, R. et al. (2005): Natalizumab Induction and Maintenance Therapy for Crohn's Disease. The New England Journal of Medicine, 353, 1912-1925. DOI: 10.1056/NEJMoa043335, https://www.nejm.org/doi/full/10.1056/NEJMoa043335

Sandborn, W. J. - Feagan, B. G. - Rutgeerts, P. et al. (2013): Vedolizumab as Induction and Maintenance Therapyfor Crohn's Disease. The New England Journal of Medicine, 369, 711-721. DOI: 10.1056/NEJMoa1215739, https://www.nejm.org/doi/full/10.1056/NEJMoa1215739

Sandborn, W. J. - Su, C. - Panes, J. et al. (2017): Tofacitinib as Induction and Maintenance Therapy for Ulcerative Colitis. The New England Journal of Medicine, 377, 496-497. DOI: 10.1056/ NEJMoa1606910, https://www.nejm.org/doi/full/10.1056/NEJMoa1606910

Yoo, D. H. - Hrycaj, P. - Mirandaet, P. et al. (2013): A Randomised, Double-blind, Parallel-group Study to Demonstrate Equivalence in Efficacy and Safety of CT-P13 Compared with Innovator Infliximab When Coadministered with Methotrexate in Patients with Active Rheumatoid Arthritis: The PLANETRA Study. Annals of the Rheumatic Diseases, 72, 1613-1620. DOI: 10.1136/annrheumdis-2012-203091, https://ard.bmj.com/content/72/10/1605.long 